\title{
Research on the Cultivation of Management Accounting Talents
}

\author{
Jiangying Xia \\ Chongqing Business Vocational College, Chongqing, 401331
}

Keywords: Accounting Talents, Cultivate Method, Management Talents

\begin{abstract}
In recent years, with the continuous development of social economy, the social requirements of accounting personnel continue to improve, enterprises urgently need to participate in the production and operation of the enterprise management and management of the daily management and management. In order to meet the changing needs of the social talents, people began to think about how to change from the traditional "operation" accounting personnel training mode to the "management" accounting personnel training mode.
\end{abstract}

\section{Introduction}

In the era of knowledge economy, enterprises need accounting personnel to use objective and real accounting information to carry out financial analysis, financial forecast and financial decision, and apply it to enterprise management. The accounting work is changed from accounting to comprehensive analysis and application of accounting information, To achieve the accounting from the accounting type to the management of the change. Modern enterprises require accounting personnel not only to master the financial accounting, cost accounting and other basic accounting skills, but also to understand the financial management, cost management, internal control principles, strategic management, internal audit, comprehensive budget management, compensation system design and performance appraisal, risk Management and other management knowledge, with accounting professional knowledge of senior accounting personnel pay more attention to data analysis and use, to help enterprises to develop development strategies for enterprises to create wealth and value, from accounting to management decision-making direction.

\section{"Management" Accounting Personnel Training Mode Positioning and Training Requirements}

"Management" accounting talent is to master the system accounting theory and rich management knowledge, familiar with international practice, with the ability to analyze and determine the strategic thinking of the composite accounting professionals, with the future business management team to become the potential of accounting experts. "Management" accounting personnel should be equipped with every senior management personnel of the ideological and moral quality, cultural quality, scientific quality and physical and mental quality, but also should have the following professional ability: the macroeconomic understanding of the situation. System design ability. Strategic Execution Capability. Value creation ability. Risk aversion. At any time to capture the crisis signal, the ability to take timely measures; accounting work organization and coordination capacity.

We believe that the goal of accounting personnel training is not only to train the needs of the talent market, with rich professional knowledge of the accounting staff, but also need to develop to adapt to the accounting environment, the management of environmental change of innovative accounting personnel. Accounting education is not only to lay a solid professional foundation of students, but also to develop students the ability to study for life. "Management" accounting talent is to master the system of accounting theory and rich management knowledge, familiar with international practice, with international vision and strategic thinking of the composite accounting professionals, with the future business management team to become the potential of accounting 
experts. "Management" accounting personnel from the traditional "accounting operation" to "professional management" until "integrated management" change. In addition to the "moral management", "management" talents should have the following professional ability: (1) the understanding of the macroeconomic situation, in addition to the ideological and moral quality, cultural quality, scientific quality and physical and mental quality of each senior talent. (2) system design ability: accounting system design, internal control system design, responsibility system design, budget preparation, salary system design, equity structure design; (3) strategic implementation of the system of design, Capacity management ability, tax planning ability, resource management ability, resource allocation, assessment of the comprehensive ability; (5) risk aversion ability: at any time to capture the ability to manage the risk of capital management, Crisis signal, the ability to take timely measures; (6) financial management organization coordination capacity: accounting work organization and leadership, communication and coordination skills and ability to solve problems. Through the reform of "management" accounting personnel training mode, the economic management foundation of accounting students will be more generous and solid, professional vision will be more broad, students' organizational management ability, self-knowledge ability, analysis and problem solving ability, Chinese and English ability to express and other advantages will be further consolidated, at the same time, students macroeconomic situation to determine the ability to comprehensive analysis, professional judgment, system design capabilities, strategic management and other professional skills to be trained, after graduation can quickly grow into business management The team's accounting experts, for the development of China's enterprises to make greater contributions.

\section{Management Accounting Personnel Should have the Knowledge Structure}

According to the modern enterprise management and economic situation development needs, management accounting personnel should be integrated with the following knowledge structure:

Master the basic modern economic and management theory, familiar with the modern enterprise production and operation process, pay close attention to the capital market and financial market development changes, according to the external environment changes and enterprise development strategy at any time to develop appropriate strategies and contingency measures.

Proficient in basic accounting theory and accounting professional knowledge, fully understand the international accounting standards, proficient in the use of computer accounting and data processing, business management decision-making to provide the necessary information.

Strong ability to predict and analyze. The senior accounting personnel with accounting professional knowledge and forecast analysis ability pay more attention to data analysis and application than accounting personnel, and accurately forecast and make decisions according to their own financial situation and industry development law. Management accounting personnel should also have strong organizational coordination and communication skills, independent learning ability and comprehensive innovation ability to adapt to the internal development of enterprises and changes in the external environment to complete the accounting functions from accounting to management-oriented changes in the function.

Third, the accounting professional personnel training system Research management of financial accounting staff should be integrated with economics, business management, finance, computer operation and data processing capabilities, innovation, organizational and inter-organizational communication and coordination. In order to cultivate qualified management accounting personnel, accounting courses and teaching methods should be corresponding to the reform and innovation. In order to realize the training objectives of management accounting professionals, it is necessary to combine the knowledge structure and ability requirements of management accounting talents, to supplement and perfect the curriculum, to explore the establishment of management-oriented accounting personnel training program, and through the teaching methods and teaching reform Innovate, cultivate and perfect the knowledge structure and quality ability of management accounting professionals, and establish the training mode of management accounting personnel. 
According to the knowledge structure and quality ability of management accounting personnel, in order to meet the requirements of management organization, it is necessary to set up curriculum modules in the curriculum and teaching reform of accounting specialty, and to improve the theoretical basis of accounting personnel And comprehensive quality.

Economic and management basic theory modules: including microeconomics, macroeconomics, management, corporate strategy and risk management, marketing management, production and operation management, corporate governance, industrial economics and other courses. The purpose of this part of the course module is to enable students to understand the basic business management knowledge and production process, to expand the student's knowledge structure, learning the basic modern economic and management theory.

Financial knowledge module: including basic accounting, financial accounting, senior financial accounting, cost accounting, financial management, management accounting, auditing, finance, international accounting courses. The purpose of this part of the course module is to enable students to master the basic knowledge of accounting, learning basic accounting methods and financial statements preparation process, master basic accounting theory and accounting expertise.

Forecasting and analysis module: including financial analysis, tax planning, capital operation and management, capital market research, econometrics and other courses. This part of the course module in the basic knowledge of the basic enterprise economic management and accounting professional knowledge on the basis of learning and corporate finance, investment activities related to the theoretical knowledge, how to use the financial accounting information provided by the decision-making analysis. The teaching mode, course system and personnel training mode of accounting specialty must be suitable for the needs of modern enterprises to manage accounting talents. Combining with the knowledge structure of management accounting talents, it is necessary to set up curriculum system and reform teaching method to cultivate qualified accounting for modern enterprise Talent.

\section{Management Strategy of Accounting Talents}

To carry out "teaching as the leading, learning as the main" teaching content and teaching methods of reform. (1) to carry out the teaching content system reform, optimize the course content. To carry out the teaching concept and teaching content of the discussion, according to the "accounting and management combined with" the idea of "accounting course system", "financial management curriculum system", "internal control curriculum system", "computer accounting course system" and other curriculum system optimization and integration , The existing curriculum of the teaching content of a comprehensive optimization, to update the syllabus, to promote teacher classroom teaching to achieve "management" personnel training. To carry out case teaching. Appropriate collection, the preparation of real economic life in accounting theory and accounting practice are closely linked, vivid and intuitive, triggering student's in-depth thinking of teaching cases. Through the case teaching to analyze the comprehensive economic business of the enterprise, from a point of view of the introduction of a topic of discussion, so that students put into a series of well-designed in the well-designed case discussion, so that students play a more proactive The role of the actual economic issues from the interest, so that students understand the accounting practice may encounter practical problems and solutions to guide students not only know the case, and know why. (3) create a professional website. To carry out a variety of online discussions, counseling, solutions, practice, the implementation of network of teachers "teaching", students "learning" and electronic assessment and online education. So that students in the online dialogue between each other for the exchange; to provide a platform for teachers to ask the teacher; the establishment of online exams to facilitate students to better understand the book knowledge; through the Internet from time to time in a timely manner to update the relevant chapter exercises, Specify the time to conduct online answers, you can test the usual results of learning; by uploading some of the latest financial information on the site, so that students of the professional and knowledge of the professional knowledge, expand their horizons, rich knowledge. (4) through the "please come in, go out" approach, invited large and medium-sized enterprises, chief accountants, chief financial 
officers and experienced financial managers to the school lectures to achieve practical and theoretical communication; At the same time we also organize teachers and Students to the enterprise to research and practice, to stimulate students concerned about the practical problems of the enthusiasm of the enterprise, greatly enriched the students to analyze and solve the practical problems of the ability to stimulate students concerned about the practical problems of the enthusiasm of enterprises. 2. To create a "high level, double teacher" teaching team. First, through the outside cited, the training of personnel training measures to optimize the qualifications of teachers and title structure; the second is through the enterprises in the exercise, in the community to take or participate in accounting, auditing practice to improve the teacher's practical teaching ability. Forging a theoretical foundation, but also with the actual skills of the double division of professional team. So that the relevant teachers, not only capable of theoretical teaching, but also to undertake the relevant aspects of the horizontal issues, the scientific research into experimental teaching. At the same time under the leadership of the teachers, so that accounting students can practice some of the specific work of the operating methods, so that in the employment competition can be in a dominant position. 3. Establish the "diversity of forms, capacity assessment" assessment methods. Strengthen the examination evaluation reform, highlight the ability to assess, to test the wind to promote teaching style and style of study. Reform the examination evaluation method, increase the students classroom case discussion, course papers, practice research scores, reduce the rote test, the actual case of the case analysis content into each course of the exam, to carry out professional examinations and other test methods reform, Students to understand the depth of the ability to analyze the problem and comprehensive assessment of the ability to assess the assessment to promote the teaching style and style of study.

\section{Conclusion}

The more economic development, the more important accounting. The rapid and rapid development of economic globalization and the profound changes in the domestic and international economic environment require financial and accounting personnel not only to master the professional knowledge and skills of accounting, finance and finance, to understand business rules, to have the ability to use modern technology for information processing and analysis ; Also familiar with the whole process of business management, with good professional ethics, healthy psychological quality, with the overall concept and organizational coordination, keen insight, open thinking and innovation awareness, and the ability to study for life.

\section{Acknowledgements}

Fund Project: This article is the key project of Chongqing higher education teaching reform research "under the guidance of" management type "under the guidance of higher vocational accounting professional talents training research and practice" (No. 162088) stage research results

\section{References}

[1] Wang Wenhua, Wang Weixing. Management accounting personnel positioning and training model [J]. Finance and Accounting. 2013 (22)

[2] Song Ming, Ma Jiaqiao. Talking about the conversion of accounting accounting to management accounting [J]. Heilongjiang Science and Technology Information. 2013 (11)

[3] Wang Wenhua. On the management of accounting personnel training [J]. Education and Teaching Forum. 2013 (41)

[4] Qi Chao.Study on the New Management Accounting under the Background of Information [J]. Finance and Economics. 2012 (08)

[5] Liang Yujuan, Shen Shu new. On accounting accounting to management accounting [J]. Science 
and Technology Information (Science and Education) .2007 (18)

[6] Fan Zhanzhu. On accounting accounting to management of accounting conversion [J]. Friends of Accounting. 2003 (01) 